\title{
Habitat and abundance of the Neotropical otter (Lontra longicaudis annectens) in Pueblo Nuevo, Durango, Mexico
}

\author{
Francisco Cruz García ${ }^{1 *}$, Armando Jesús Contreras Balderas ${ }^{1}$, Rigel Nava Castillo and Juan Pablo Gallo Reynoso ${ }^{2}$ \\ ${ }^{1}$ Laboratorio de Ornitología, Facultad de Ciencias Biológicas, Universidad Autónoma de Nuevo León, Río Parana 246 Colonia \\ Loma Bonita, Cp. 34197, Durango. Duango, México. Email: guarimochi 494@hotmail.com (FCG)_ornitología@gmail.com (ACB) \\ rigela@hotmail.com (RNC). \\ ${ }^{2}$ Centro de Investigación en Alimentación y Desarrollo A. C., Unidad Guaymas. Carretera a Varadero Nacional km 6.6. Col. Las \\ Playitas 85480. Guaymas, Sonora. México. Email: jpgallo@ciad.mx (JGR). \\ * Corresponding author
}

La nutria neotropical es un depredador ubicado en el nivel trófico superior, su distribución geográfica abarca desde el norte de México hasta la zona central de Argentina. Habita en las riberas de los ríos, donde puede realizar actividades de descanso, juego, marcaje de territorio, limpieza de pelaje y cría de cachorros. Lontra longicaudis es sensible a cambios en su hábitat, ya sea por la degradación de los ambientes de ribera como la contaminación de los cuerpos de agua, por lo que se le considera un indicador de la degradación de los ecosistemas acuáticos. Actualmente, se encuentra dentro de la categoría de amenazada de acuerdo a la NOM-059-SEMARNAT-2010. El objetivo del presente trabajo es caracterizar el hábitat y determinar la abundancia de la nutria neotropical en la parte alta del Río San Diego, para conocer si la abundancia poblacional de la nutria depende directamente de las características del hábitat y de la dinámica estacional. El monitoreo se realizó durante dos años (2012-2013), se muestrearon 8 kilómetros sobre el río, los cuales se dividieron en 3 segmentos de igual tamaño, ya que en base a recorridos preliminares, se pudo observar de manera general que presentaban características físicas y ambientales diferentes. Se midieron los parámetros fisicoquímicos del agua, se identificaron las especies de flora a las orillas del rio, se colectaron 266 heces y se obtuvo la abundancia relativa de la nutria. El segmento 1 presentó un $\mathrm{pH}$ del agua ácido, con temperaturas frías y especies de los géneros: Pinus, Quercus y Juniperus sobre las orillas del cauce; en el segundo segmento se encontró un pH neutro, con temperaturas más cálidas, se observó poca presencia de vegetación de ribera; en el tercer segmento nuevamente se observó vegetación ribereña, con aguas cálidas y un pH próximo a neutro. Se determinó una abundancia relativa promedio de la población de 0.46 nutrias $/ \mathrm{km}$. Se obtuvo un modelo para la predicción de abundancia de nutrias con un error de predicción de \pm 0.27 nutrias $/ \mathrm{km}$. Las características del hábitat de la nutria en esta zona coinciden con lo descrito por otros autores para otros lugares del país, con pH neutro, aguas limpias con alto valores de oxígeno disuelto, con temperaturas del agua mayormente frías en las partes altas, presencia de vegetación ribereña, con tramos de rápidos y baja profundidad y zonas con pozas de aguas lentas y profundas. Por otra parte, la abundancia de la nutria obtenida se encontró dentro de un rango de diferentes valores obtenidos por otros autores, el cual varía de entre los 0.21 nutria/km a 1.22 nutrias $/ \mathrm{km}$, pero igualmente este valor no fue fijo, sino que varió dentro del periodo de muestreo, para este caso, en la temporada de lluvias disminuyó y en temporada de secas aumentó. El modelo relación abundancia-hábitat presentó ajustes aceptables; sin embargo, las variables más significativas fueron el total de sólidos disueltos, el pH, la zona de flujo y la profundidad. Este estudio permitió conocer la situación actual de la nutria en esta área y las condiciones de su hábitat; no obstante, es necesario realizar más estudios que generen mayor conocimiento de esta especie y poder tomar decisiones e implementar acciones para su conservación.

The Neotropical otter is a predator located in the upper trophic level; its geographical distribution stretches from northern Mexico to central Argentina. It lives in river banks, where it rests, plays, marks its territory, cleans its fur and breeds its offspring. Lontra longicaudis is sensitive to alterations in the habitat, either by the degradation of river bank environments and by pollution of water bodies; hence, it is considered as an indicator of the degradation of aquatic ecosystems. This species is currently included in the threatened species category according to NOM059-SEMARNAT-2010. The aim of this work is to characterize the habitat and determine the abundance of the Neotropical otter in the upper part of San Diego River, to assess whether the sea otter population abundance is directly related on the characteristics of the habitat and the seasonal dynamics. The monitoring was carried out over two years (2012-2013). Eight kilometers along the river were sampled considering 3 segments of equal length, since preliminary visits revealed that these had distinctive physical and environmental characteristics. The physicochemical parameters of water were measured, plant species growing along the river bank were identified, 266 samples of feces were collected, and otter relative abundance was estimated. Segment 1 showed an acid water $\mathrm{pH}$, with low temperatures and plant species of the genera Pinus, Quercus and Juniperus along the river banks; the second segment showed a neutral $\mathrm{pH}$, with higher temperatures, and scarce riparian vegetation; the third segment again displayed riparian vegetation, with warm water and near-neutral $\mathrm{pH}$. The relative abundance determined for the otter population averaged 0.46 otters $/ \mathrm{km}$. A model for predicting otter abundance was obtained, which yielded a prediction error of \pm 0.27 otters $/ \mathrm{km}$. The characteristics of the habitat associated with otters in this area were similar to those described by other authors for other parts of the country, namely a neutral $\mathrm{pH}$, clean oxygen-rich waters, low water temperature in the upper portions of the river, presence of riparian vegetation, with stretches of rapids and shallow areas with pools of slow-flowing, deep water. Separately, the abundance of otters found in this case lied within a range that differed from the one reported by other authors, which varies between 0.21 and 1.22 otters/km; again, this was not a fixed value, but varied over the sampling period: it decreased in the rainy season and rose in the dry season. The abundance-habitat relationship model showed an acceptable fit; however, the most significant variables were total dissolved solids, $\mathrm{pH}$, flow zone and depth. This study made possible to determine the current status of the otter and the conditions of its habitat in this area; however, further studies are needed to gain a detailed understanding on the species to support decision-making and implement conservation actions. 


\section{Introduction}

Estimates of the population size and the definition of habitat use of wild mammals are factors of paramount importance for management and/or conservation purposes; these parameters can provide key information for decisionmaking in relation to these populations (Sutherland 2006). Population abundance and distribution vary in space and time, along with the availability of environmental elements needed to sustain life (Litvains et al. 1996).

The habitat provides food, coverage, shelter and other factors that are essential to the survival of populations. Many ecological research in mammal populations, such as those focused on estimating abundance, the condition of pupulations (Dellafiore and Maceira 1998; Richard et al. 1998; Walker et al. 2000), and the use of their environment, provide key information for long-term conservation and management (Samuel et al. 1985).

The studies of habitat use consider the environment where animals conduct their activities (Litvains et al. 1996). This depends on the interaction of various environmental and ecological factors that affect habitat quality, being unique for each species, influenced by dietary requirements and rest and shelter areas, as well as by seasonality, which often involves the adoption of a number of strategies for the use of spaces (Tellería 1986; Bello et al. 2002; GuzmánLenis and Camargo-Sanabria 2004; Noss et al. 2003).

In particular, otters live in areas that meet certain requirements, including a wide riparian vegetation and an

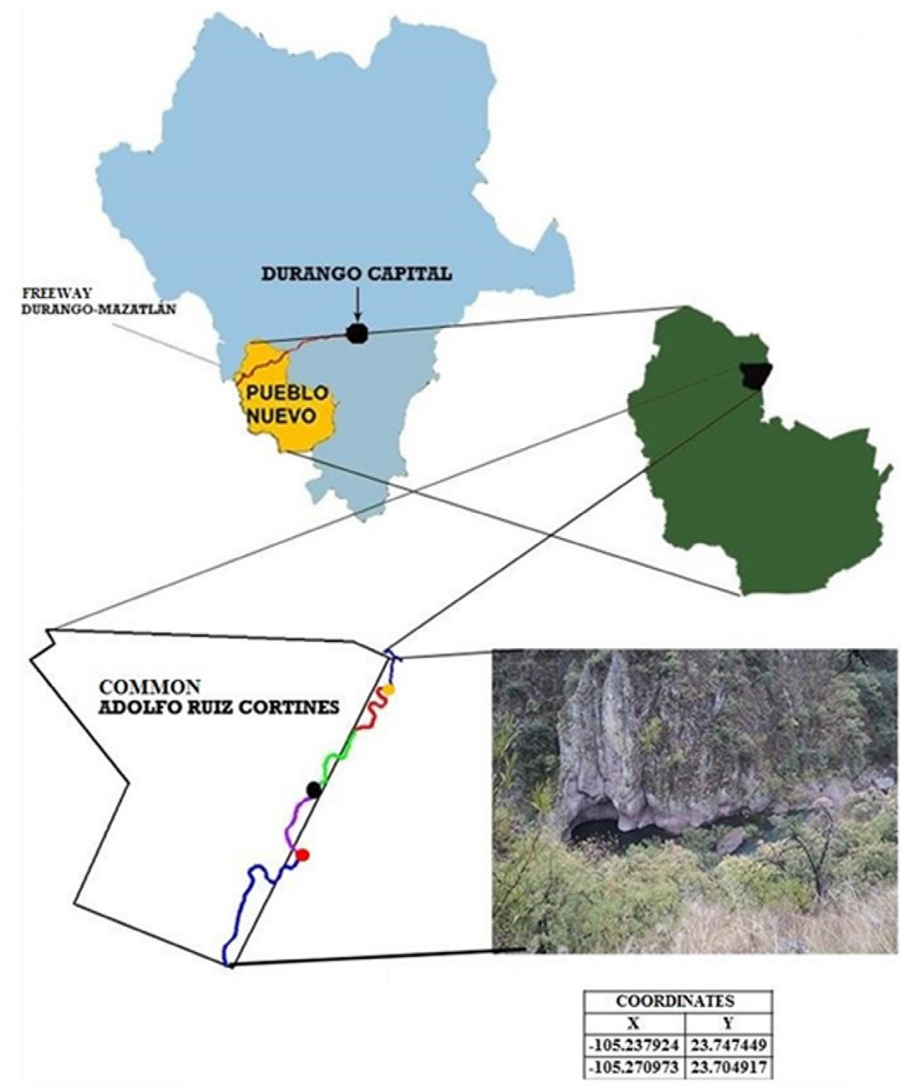

Figure 1. Location of the study area in San Diego River $\left(23.737^{\circ} \mathrm{N}\right.$ and $\left.-105.298^{\circ} \mathrm{W}\right)$, Durango, Mexico. adequate vegetation cover (Colares and Waldemarin 2000a; Gori et al. 2003; García Botello and Quintana 2005), since in the river banks they carry out activities such as rest, marking of territory, cleaning of fur, and breeding of offspring (Chanin 1985; Kruuk 1995). Similar to most mammal species, Lontra longicaudis is sensitive to drastic alterations in the habitat, to the degradation of river bank environments and to pollution of water bodies; hence, it is considered as an indicator of the degradation of aquatic ecosystems (Lodé 1993).

Leopold (1959) mentions that otters are not abundant in Mexico, and given the high economic value of its fur, it is not uncommon that their populations decline under excessive hunting, because the species has a low reproductive potential (one to two offspring per female). Currently, the otter is included in the threatened category in Mexican laws according to NOM-059-SEMARNAT-2010 (SEMARNAT 2010), so that the current status of the otter in the country should be considered in order to design appropriate management strategies aiming to its conservation. In addition, this species is included in CITES Appendix I (CITES 2016), and in the Red List of threatened species in the near threatened category (Rheingantz and Trinca 2015).

Particularly, records on the presence of otters in the state of Durango are scarce. Baker and Greer (1962) mention that local inhabitants have seen otters in the same river where this research was conducted (San Diego river), although downstream. Servín et al. (2003) reported the presence of otters in Arroyo El Alemán, municipality of Súchil, through the tanned fur of an animal hunted on 2 January 1994; also, Charre-Medellin et al. (2011) found excreta along the Mezquital river bank but did not determine the abundance of otters in this site.

A successful management and conservation of otters requires establishing the distribution and abundance of this species (Ruiz-Elm et al. 2001). Therefore, the aim of this work is to characterize the habitat of the otter and estimate its population abundance in the upper part of San Diego River, in order to determine if otter relative abundance depends directly on the characteristics of the habitat or if the otter population fluctuates between seasons or throughout the year.

\section{Materials and Methods}

Study area. The work was conducted in Quebrada de Galindo, located at ejido Adolfo Ruiz Cortinez (sic), municipality of Pueblo Nuevo, Durango, Mexico, specifically on the upper part of San Diego river $\left(23.737^{\circ} \mathrm{N},-105.298^{\circ} \mathrm{W}\right)$, located in southwestern Durango at a mean altitude above sea level of 1,760 m for segment 1, 1,770 m for segment 2 , and 1,692 $\mathrm{m}$ for segment 3 (Figure 1). The main climate types are temperate subhumid and semi-cold subhumid (Garcia 1981). The vegetation in the upper portions is composed of mixed forest dominated by the genera Pinus and Quercus, while river banks include riparian vegetation com- 

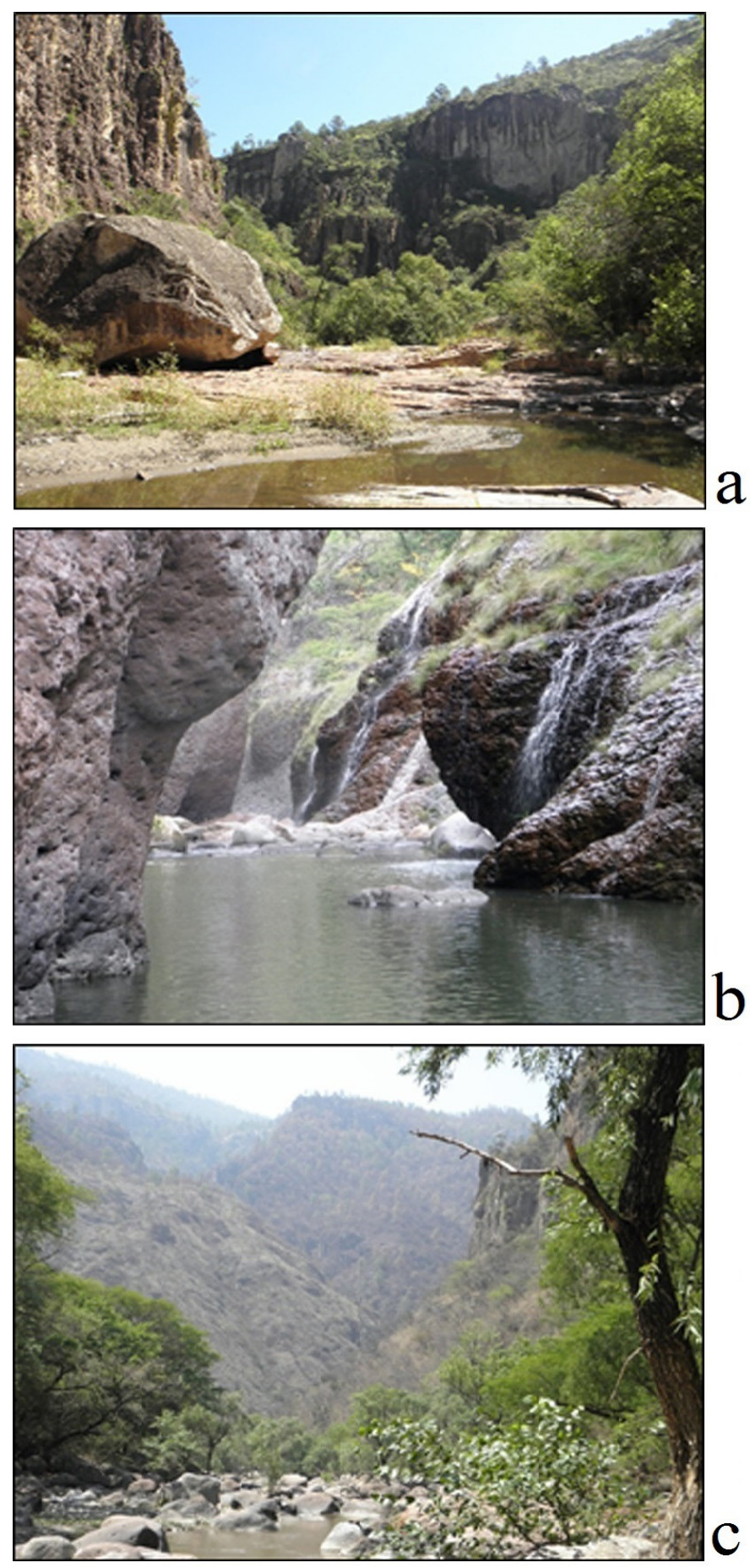

Figure 2. Outlook of the San Diego River habitat in the first segment (a), second segment (b), and third segment (c).

posed of trees of the genera Salix, Populus, Bursera, Lysiloma and Pithecellobium.

Characterization of the otter habitat. Through monthly visits, eight kilometers of the river were sampled for two years (2012 - 2013). These were divided into three segments of identical length $(2.6 \mathrm{~km})$, as preliminary visits revealed that these had distinctive physical and environmental characteristics. In each segment, an area comprising the flow zones to study, lentic (pools) and lotic (rapids), was located. These flow zones were selected as preliminary visits revealed a greater amount of excreta on the banks of pools relative to rapids; hence, one objective was to determine the potential relationship of water flow with otter presence or absence. In addition, food availability (fish) for otters was sampled in pools and rapids along the three river segments to explore whether this parameter was related to the presence of excreta.

In each flow zone, water physicochemical parameters $(\mathrm{pH}$, temperature, dissolved oxygen and total dissolved solids) were recorded using a YSI 556 MPS multi-parameter probe once per season of the year: spring (March, April and May), summer (June, July and August), fall (September, October and November) and winter (December, January, February). In addition, the river width and depth were measured with a 15-m flexometer; the depth was measured by dropping the flexometer to the bottom and reading the tape at the water mirror (Macías-Sánchez 2003). In each segment, a $5 \mathrm{~m}$-wide strip was sampled from the edge of the river to the forest on each side of the river, the tree and shrub species present in the area were identified whenever possible (Ruiz-Olmos et al. 1998). To determine which flow zone (pools or rapids) had the highest amount of fish, a sampling was conducted with a seine net ("chinchorro") in each segment and flow zone once a month; these values were used to calculate the mean fish catch in each flow zone (Macías-Sánchez 2003).

Otter relative abundance. The rocks and fallen trees used as latrines by otters were identified during trips. A latrine was defined as any component of the habitat that showed at least one otter feces. For each latrine, its geographical position (latitude and longitude) was recorded with a Garmin GPS; the number of feces found, which were removed at each sampling, considering only those that were either recent or dry but complete (i. e., well-formed and not disintegrated).

The number of feces and latrines were used to calculate three otter relative abundance indices for each river segment according to Macias-Sánchez (2003), considering: 1) the number of feces divided by the total kilometers traveled $(\mathrm{NE}) ; 2$ ) the number of latrines divided by the total kilometers traveled (NL); and 3 ) the number of feces divided by the defecation rate and total kilometers traveled (AN). We used the defecation rate estimated by Gallo-Reynoso (1996), i.e. three defecations per day, based on two female otters in captivity (Macías-Sánchez 2003). The comparison in the number of feces between segments and between months (January to December) was carried out using a completely random single-factor analysis of variance (Zar 1999).

Relationship between otter abundance and habitat variables. A multinomial logistic regression was applied using the program SPSS Statistics 21, to obtain a model and determine the relationship of otter population abundance with habitat variables (water physicochemical parameters and area) used for the habitat characterization (Johnson and Wichern 2002). To incorporate the vegetation variable to the statistical analysis, categorical values were assigned 


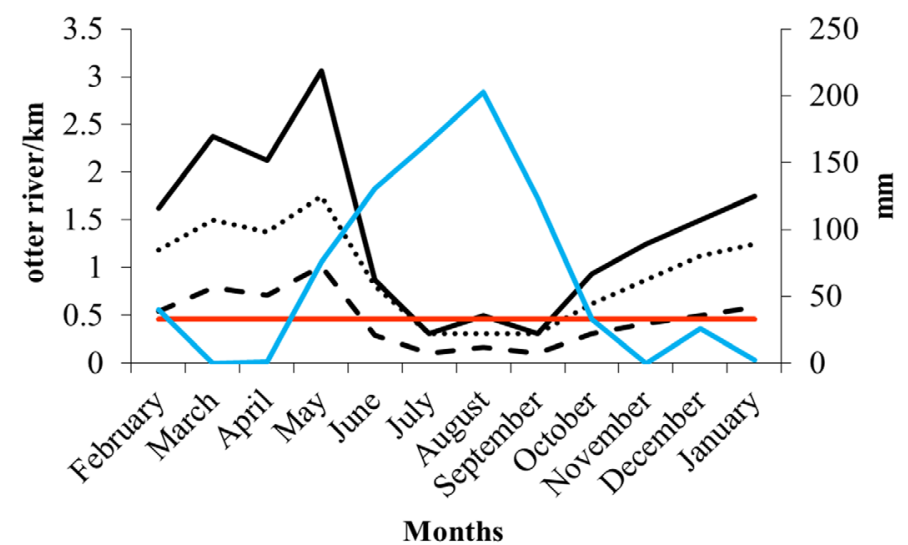

Figure 3. Relationship between mean monthly rainfall and abundance of the otter Lontra longicaudis annectens in the two years of sampling (2012 to 2013) in San Diego River. Number of feces per kilometer of river (NE), number of latrines per kilometer of river $(\mathrm{NL})$, and the number of otters per kilometer of river (AN).

to the presence of vegetation on the river banks by segment; in the case of the second segment the value assigned was zero since vegetation was scarce in the steep mountain slopes. Average fish caught were compared between flow zones using a single-factor analysis of variance (Zar 1999).

\section{Results}

Habitat characterization. The first segment (Figure 2a) was characterized by a shallow channel ranging between $0.7 \mathrm{~m}$ and $1.3 \mathrm{~m}$ depth in river rapids and between $1.6 \mathrm{~m}$ to $2.2 \mathrm{~m}$ in pools. Winter was the season with the lowest temperature, which fluctuated between $9.5^{\circ} \mathrm{C}$ and $13.2^{\circ} \mathrm{C}$. The pH was acid in pools of this segment, ranging between 4.34 and 6.45, dissolved $\mathrm{O}_{2}$ varied between 8.98 to $12.25 \mathrm{mg} / \mathrm{l}$, and total dissolved solids ranged from $0.059 \mathrm{~g} / \mathrm{l}$ to 0.109 $\mathrm{g} / \mathrm{l}$. High $(45 \mathrm{~m})$ but separate mountain walls, with minimum and maximum end-to-end distances of $4 \mathrm{~m}$ and 17 $m$, respectively, bordered this river segment (Table 1$)$. The dominant tree species observed along the channel in this segment were the genera Pinus, Arbutus, Juniperus, Quercus, and some Salix bonplandiana specimens. Two otter dens were observed on the river banks in strategic locations. These areas were protected by the local relief, namely a rocky outcrop protruding from the edge of the channel into its center, serving as a barrier against upstream rising waters; vegetation that accumulated in the pool downstream to the outcrop served as protection for otters to build their dens.

The second segment (Figure $2 \mathrm{~b}$ ) runs across a ravine, the bordering walls were $30 \mathrm{~m}$ in maximum height, separated by a distance ranging from 4 to $7 \mathrm{~m}$; water depth was between $3.4 \mathrm{~m}$ to $6.5 \mathrm{~m}$ at pools and between $1 \mathrm{~m}$ to $1.4 \mathrm{~m}$ in rapids. During the sampling period, $\mathrm{pH}$ ranged between 6.99 and 8; dissolved O2, from 9.41 to $9.71 \mathrm{mg} / \mathrm{l}$; and water temperature, from $21.2^{\circ} \mathrm{C}$ to $28.1^{\circ} \mathrm{C}$ (Table 1). This segment was characterized by absence of riparian vegetation due to the steep mountain walls, with only some species of the genera Agave and Bursera, as well as grasses that managed to survive on cliffs. A distinctive feature observed in this section that differentiated it from the other two was the presence of thermal water streams from springs located in the upper parts of the surrounding mountains and falling on the walls of rocks to reach some of the pools along this stretch of the river. No sites that were suitable for otters to build their dens like those observed in the first segment were observed in this area.

The third segment (Figure 2c) was strikingly different from the second, cliffs are not observed and river banks are suitable for riparian vegetation with species like Salix bomplandiana, Buddleja cordata, Fraxinus udhei, Prunus serotina, Populus tremuloides and Lysiloma sp, Bursera sp, Pithecellobium dulce. This area showed a wider channel, averaging $13 \mathrm{~m}$ from shore to shore, with a maximum depth of 4.8 $\mathrm{m}$ in pools and a minimum of $1.3 \mathrm{~m}$ in rapids; dissolved $\mathrm{O}_{2}$ ranged between 7.02 and $8.79 \mathrm{mg} / \mathrm{l}$ and total dissolved solids ranged from 0.094 to $0.11 \mathrm{~g} / \mathrm{l}$. In this segment, water temperature remained below $22.3{ }^{\circ} \mathrm{C}$, but did not drop below $20.1^{\circ} \mathrm{C}$, and $\mathrm{pH}$ ranged from 5.3 to 5.9 (Table 1). As in the first segment, an otter den was also observed.

Otter relative abundance. A total of 266 feces were recorded throughout the two years of sampling, the larg-

Table 1. Physicochemical variables of water per season and segment for the two years of sampling (2012 - 2013) in San Diego River, Durango. Physicochemical variables of water per climatic season and segment (seg), water temperature (Tp), total dissolved solids (Ts), dissolved oxygen (Od), pH, flow zone (Zf), channel width (Ac), depth (Pf) and height of walls (Ap), slow-flowing water (pools) and fast-flowing waters (rapids).

\begin{tabular}{|c|c|c|c|c|c|c|c|c|c|}
\hline Station & Seg & $\operatorname{Tp}\left(C^{\circ}\right)$ & $\begin{array}{l}T \quad s \\
(g / l)\end{array}$ & $\begin{array}{l}0 \quad \mathrm{~d} \\
(\mathrm{mg} / \mathrm{l})\end{array}$ & $\mathrm{pH}$ & Zf & $\begin{array}{l}\text { Ac } \\
(\mathrm{m})\end{array}$ & $\begin{array}{l}P \quad f \\
(m)\end{array}$ & $\begin{array}{l}\text { A p } \\
\text { (m) }\end{array}$ \\
\hline \multirow{6}{*}{ winter } & 1 & 9.52 & 0.078 & 10.53 & 4.34 & pool & 12 & 1.6 & 45 \\
\hline & 1 & 14.33 & 0.068 & 12.25 & 6.45 & rapid & 14 & 0.7 & 40 \\
\hline & 2 & 21.44 & 0.094 & 9.41 & 6.99 & pool & 6.5 & 3.7 & 30 \\
\hline & 2 & 21.22 & 0.093 & 10.07 & 7 & rapid & 5 & 1.2 & 8 \\
\hline & 3 & 20.39 & 0.096 & 8.18 & 5.71 & pool & 12 & 3.8 & 5 \\
\hline & 3 & 20.30 & 0.094 & 8.61 & 5.97 & rapid & 12 & 1.5 & 0 \\
\hline \multirow{6}{*}{ spring } & 1 & 10.60 & 0.109 & 8.98 & 4.37 & pool & 9 & 1.5 & 45 \\
\hline & 1 & 15.31 & 0.107 & 9.09 & 5.88 & rapid & 7 & 1 & 40 \\
\hline & 2 & 28.11 & 0.099 & 9.87 & 7.06 & pool & 5.4 & 4.2 & 30 \\
\hline & 2 & 24.23 & 0.100 & 11.14 & 7.87 & rapid & 4 & 1 & 8 \\
\hline & 3 & 22.29 & 0.101 & 8.15 & 5.51 & pool & 12 & 3 & 5 \\
\hline & 3 & 21.32 & 0.11 & 7.02 & 5.77 & rapid & 10.5 & 1 & 0 \\
\hline \multirow{6}{*}{ summer } & 1 & 11.27 & 0.059 & 11.97 & 4.46 & pool & 7.7 & 2.2 & 45 \\
\hline & 1 & 15.52 & 0.081 & 9.45 & 5.69 & rapid & 8.2 & 1.3 & 40 \\
\hline & 2 & 24.69 & 0.062 & 9.65 & 8 & pool & 7 & 6.5 & 30 \\
\hline & 2 & 22.73 & 0.078 & 9.41 & 7.33 & rapid & 6 & 1.4 & 8 \\
\hline & 3 & 20.99 & 0.084 & 8.33 & 5.5 & pool & 13.1 & 4.8 & 5 \\
\hline & 3 & 21.46 & 0.092 & 8.79 & 5.39 & rapid & 14 & 1.5 & 0 \\
\hline \multirow{6}{*}{ fall } & 1 & 13.24 & 0.067 & 10.23 & 4.68 & pool & 6 & 1.9 & 45 \\
\hline & 1 & 17.52 & 0.089 & 11.46 & 5.81 & rapid & 5 & 0.9 & 40 \\
\hline & 2 & 23.33 & 0.078 & 9.56 & 7.06 & pool & 6.5 & 3.4 & 30 \\
\hline & 2 & 21.89 & 0.068 & 9.37 & 7.87 & rapid & 5 & 1.2 & 8 \\
\hline & 3 & 20.12 & 0.094 & 8.51 & 5.51 & pool & 12.3 & 4.5 & 5 \\
\hline & 3 & 21.78 & 0.096 & 8.75 & 5.77 & rapid & 14 & 1.3 & 0 \\
\hline
\end{tabular}


est number was collected between January to May ( $n=$ 189), which corresponds to the dry season for this region; the mean relative abundance (AN) for the entire sampling period was $\mathrm{AN}=0.46$, with a confidence interval of \pm 0.16 otters $/ \mathrm{km}$. The highest value was observed in May with 1.02 otters $/ \mathrm{km}(n=49)$, and the lowest in the rainy season in July and September, with AN $=0.104$ otters $/ \mathrm{km}(n=5)$ in each month. The abundance indices NE and NL were positively related to one another over the sample period, i.e., when the number of feces increased, the number of latrines also did, and vice versa (Figure 3). The only significant differences were recorded in the number of feces in May vs. July and September $(\mathrm{F}=2.6 ; P=0.02)$, the latter corresponding to the rainy season. A higher number of feces $(n=108)$ was found in the second segment, and the lowest number of feces $(n=59)$ occurred in the first segment; this difference was not statistically significant (Figure 4).

Habitat-abundance relationship. A model to predict otter abundance based on the habitat physicochemical variables was derived $(A b) . A b=-0.2542-0.023(T)+21.724$ $(\mathrm{Ts})+0.082(\mathrm{Od})+0.433(\mathrm{pH})-1.028(\mathrm{Zf})+0.058(\mathrm{Ac})-0.308$ (Pr) $-0.035(\mathrm{Vr})$.

This model indicates that as water temperature $(T)$ rises, otter relative abundance decreases; the opposite is true in relation to dissolved solids (Ts), dissolved oxygen (Od) and $\mathrm{pH}$, i. e., abundance rises as the values of these variables increase. On the other hand, there is a higher otter relative abundance in pools and shallow areas (Zf), where the channel is not narrow $(A c)$ and riparian vegetation $(\mathrm{Vr})$ is scarce. Significant differences were found between flow zones regarding the presence of fish $(F=5.35 ; P=0.03)$, with the highest number of specimens observed in pools (Figure 5).

\section{Discussion}

Habitat characterization. The habitat of the Neotropical otter in the study area coincides with the description by Casariego-Madorell et al. (2008), who found that the $\mathrm{pH}$ of water ranged between 6 and 7 in Ayuta River, state of Oaxaca. Mason and Macdonald (1987) found that otters (Lutra lutra) in a Welsh region were absent in areas where water

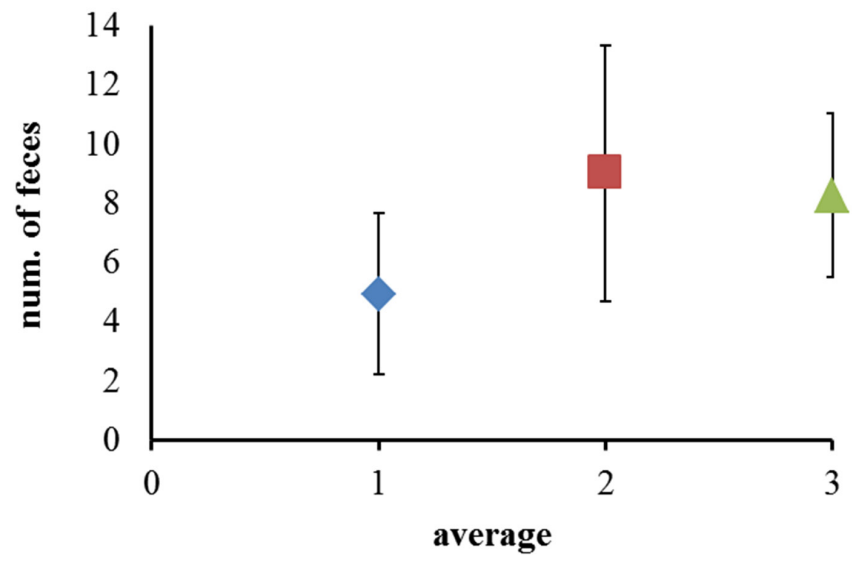

Figure 4. Mean number of feces of the otter Lontra longicaudis annectens per segment (seg) of San Diego River, Durango, Mexico (mean \pm standard deviation) in the two years of sampling.
$\mathrm{pH}$ decreased to 5.5; on the other hand, Macias-Sánchez (2003), when sampling Los Pescados and Actopan rivers, in the state of Veracruz, mentions that dissolved oxygen ranged from 7.6 to $9.5 \mathrm{mg} / \mathrm{l}$ and from 8.5 to $9.5 \mathrm{mg} / \mathrm{l}$, respectively. Garcia and Quintana (2005) highlight the preference of otters for clean water with high dissolved oxygen levels in the low delta of the Paraná River, Argentina. In this study, the $\mathrm{pH}$ in the first segment was mainly acid (4.34 and 6.45), possibly because there was abundant decaying matter in some of the pools along this stretch of the river; in contrast $\mathrm{pH}$ was close to neutral in the other segments, above all in the second segment. Otter abundance dropped in the first segment, which showed similar $\mathrm{pH}$ values to those recorded in the study by Mason and Macdonald (1987).

The total dissolved solids measured in this study were lower compared with those reported by Mayor-Victoria (2008) in Río Roble, Colombia, where this author reported two values: 0.371 and $0.403 \mathrm{~g} / \mathrm{l}$, but mentions that these values were high likely because the readings were taken in the rainy season, when the river was very turbulent. This same author mentions that the river width was between 15 and $30 \mathrm{~m}$; in the study reported here, the third segment displayed the widest channel, $13 \mathrm{~m}$ on average, relative to the other two segments, which showed a narrower channel bordered by steep walls, above all the intermediate segment.

Macias-Sánchez (2003) found that water temperature increased downstream, while lower temperatures were reported in the upper portions (Los Pescados river: $27-21^{\circ} \mathrm{C}$ max.-min.; Actopan river: 25 to $24^{\circ} \mathrm{C}$ max-min). CasariegoMadorell et al. (2008) recorded a mean temperature of 25.7 ${ }^{\circ} \mathrm{C}$ in Ayuta River, Oaxaca, while average water temperatures were $24.4^{\circ} \mathrm{C}$ and $26.2{ }^{\circ} \mathrm{C}$ in Copalita and Zimatán rivers, respectively; these values are similar to those measured in the second and third segments $\left(=22.9^{\circ} \mathrm{C}\right.$ ), no like that the first segment upstream $\left(=6.67^{\circ} \mathrm{C}\right)$.

On the other hand, Casariego-Madorell et al. (2008) mention that the vegetation on the banks of Copalita and Ayuta rivers was formed mainly by species of the families Bignoniaceae and Leguminosae (species with a more tropical affinity than the genera Pinus and Quercus identified in this work); only the species Pithecellobium dulce coincides with those found in this study. This author also mentions that, in general, the portions sampled of the study rivers had walls not exceeding five meters high, with Ayuta River being shallow for the most part, and with a moderate current in both seasons of the year. This resembles to some extent our findings in the first segment, since the depth in this stretch of the river was similarly low, with pools of up to 1.3 meters in depth. The Zimatan river displayed boulders up to $5 \mathrm{~m}$ in height where there was little vegetation, composed primarily of Cactaceae (succulent species). In this work, the second segment had pools of up to $6.5 \mathrm{~m}$ in depth, very similar to what is mentioned by the last author, where vegetation was poor and was also represented by succulent species (genus Agave). A major difference is the 


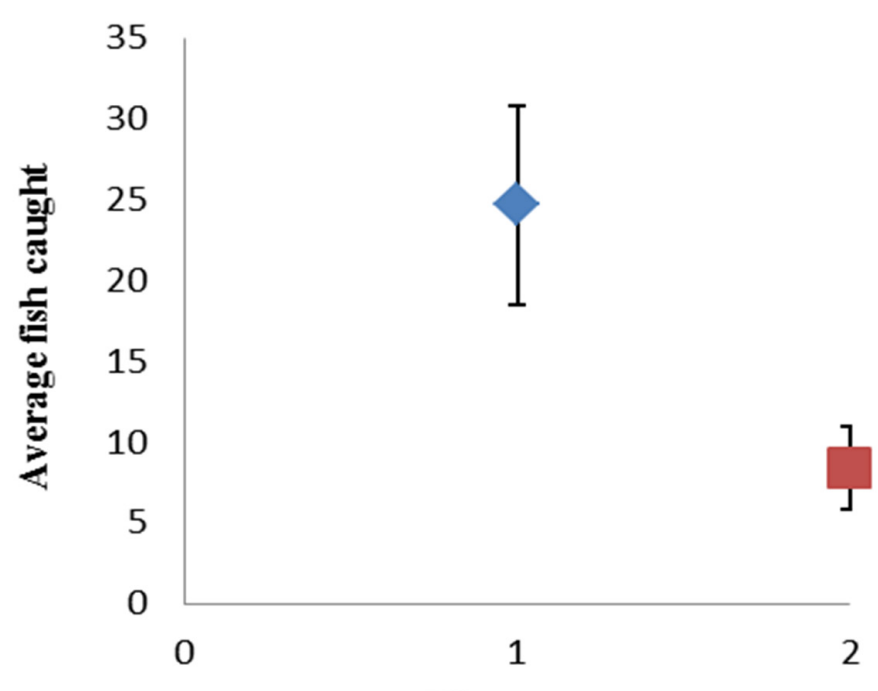

Flow zone

Figure 5. Average number of fish caught per flow zone (Rapid: Fast-flowing waters; pool: slow-flowing waters). The abundance of fish in pools is far higher than in rapids, so that the former habitat is used to a greater extent by the Neotropical otter.

condition of walls bordering the river, which were considerably higher than the five meters reported by the authors, reaching up to $45 \mathrm{~m}$ in height in some portions.

As regards the sites where utter dens were found, our observations match those reported by Arellano-Nicolas et al. (2012) who mention that dens were located in areas with dense riparian vegetation and rocky walls, representing conditions that are suitable for the establishment of otter dens. In this study, otter dens were observed in the first and third segments, which showed a higher abundance of riparian vegetation and rocky outcrops ideal for the protection of the vegetation.

Otter relative abundance. The mean relative abundance of 0.46 otters $/ \mathrm{km}$ recorded in this work differs from the figures reported by Macias-Sánchez (2003) of two and six otters $/ \mathrm{km}$ in Los Pescados and Actopan rivers, Veracruz, but were similar to 0.34 otters $/ \mathrm{km}$ determined by GalloReynoso (1996) for the Yaqui river, Sonora, and to 0.43, 0.21 and 0.52 otters $/ \mathrm{km}$ reported by Arellano-Nicolas et al. (2012); however, the latter authors reported 1.22 otters $/ \mathrm{km}$ for the rainy season, while in this study the figure of 1.02 otters $/ \mathrm{km}$ was recorded for the dry season, specifically in May. Santiago-Plata et al. (2013) also found higher values in the huracane season ( 1.12 tracks $/ \mathrm{km}$ ) versus the dry season $(0.70$ tracks $/ \mathrm{km})$, but agree that tracks decreased in the rainy season in general relative to the other two seasons (dry and huracane). On the other hand, CasariegoMadorell et al. (2008) also found a larger number of feces in the period between October and March, at the end of the rainy season and in the dry season; Duke-Dávila et al. (2013) also reported a higher abundance in the dry season compared to the rainy season. These findings coincide with the findings in this work, probably because the river flow does not increase in the dry season, preventing feces from being removed, washed away or dispersed by water when the river level rises (Aranda et al. 1980).
On the other hand, González-Christen et al. (2013) in lake Catemaco, Veracruz, Mexico, found significant differences in the abundance of otters between the four segments sampled; although otter abundance was not compared between segments, these authors calculated the differences in number of feces by segments and no significant differences emerged. However, significant differences were found between November, December, and January throughout the study $(F=5.96 ; P=0,001)$; in this work, significant differences were found in the number of feces between a dry month (May) and two months of the rainy season (July and September). On the contrary, SantiagoPlata et al. (2013) in Laguna de Terminos, Campeche, Mexico, did not find significant differences $(H=1.6 ; P<0,446)$ in the number of tracks observed between climate seasons, but significant differences were observed $(\mathrm{H}=4.96$; $P<$ $0,026)$ in the number of tracks per collection zone.

Otter relative abundance and habitat. The model showed an acceptable fit statistics, and the most significant variables were total dissolved solids, $\mathrm{pH}$, flow zone and depth. Casariego-Madorell et al. (2008) indirectly found a relationship between abundance and dissolved oxygen, with otter abundance tending to be higher in zones where dissolved oxygen was also higher; in this study a positive, relationship between dissolved oxygen and otter abundance was also observed, but it did not reach statistical significance. On the other hand, Botero-Botero (2013) mentions that the otter in La Vieja river basin, Colombia, inhabits in rivers of medium-sized and large flows; additionally, this author observed a low positive correlation between otter abundance and channel width $(=0.241 ; P=0.0001)$, and depth ( $=0.218 ; P=0.0001$ ). This same author noted a low inverse correlation between abundance and current velocity ( = $-0.238 ; P=0.001)$.

In this work, the relationship between channel width and otter abundance was also positive, as opposed to depth, with which a negative relationship was observed, and one may assume that the otter prefers rapids where depth does not exceed $1.5 \mathrm{~m}$. However, when the flow zone variable was analyzed, it was noted that the higher abundance occurred in pools. Therefore, shallow ponds could be considered the zones with the highest otter abundance for having slow-flowing water, hence agreeing with the negative relationship between abundance and current velocity reported by the author mentioned above. Our findings are similar to those reported by Lopez-Martin et al. (1998) in Bergantes River, Spain, where Lutra lutra uses low-flowing stretches and deep pools, where food and shelter are available in the dry season. Hence, the physicochemical characteristics of water likely reflect the abundance and availability of fish, as well as their probability of being captured in turbid waters relative to very clear waters.

With regard to the abundance-vegetation relationship, authors such as Colares and Waldermarin (2000b), Gori et al. (2003), García and Quintana (2005), Mayor-Victoria and Botero-Botero (2010) and Arellano-Nicolas et al. (2012) 
found a positive relationship between otter abundance and the areas with the highest plant cover. In this study, the model indicated that abundance was negatively related with the zones with the greatest abundance of riparian vegetation. However, this difference is likely due to the fact that the areas with the highest otter abundance were located in the second segment, which had the ideal characteristics as feeding grounds for otters (deep pools with greater abundance of fish), so that a higher number of tracks would be expected in these areas. Prenda and Granado-Lorencio (1996) report that the number of feces is not necessarily related to the abundance of animals, but may be related to the intensity of habitat use; accordingly, some areas may be used largely for specific activities such as feeding.

Gallo-Reynoso et al. (2016) mention that otter latrines are used as "information centers", to where the individuals of a given sector of the river go to mark and sniff out feces, urine and gels (gelatinous secretions from anal glands that apparently indicate the reproductive status) of other individuals. From the hormones in these excretions, otters identified in olfactory terms other individuals in the area and their reproductive status, whether they are in a lactating status, are adults or juveniles. Sometimes the location or physical position of latrines are independent of the presence of vegetation, deep pools or feeding areas.

In conclusion, the relative abundance of otters in the section of San Diego River sampled, lies within the range of values mentioned in other works; likewise, the local habitat agrees in most of its characteristics with those described for other areas of the country. However, since the study area is located in the limits of the altitudinal range of the species, it is necessary to further the studies on the conditions of the habitat and their relationship with otter abundance along the river. This will make possible to better understand the ecology of otters and develop environmental and social conservation strategies (environmental education) needed to preserve the otter in San Diego River, Durango.

\section{Acknowledgments}

To CONACyT for the support with the Ph. D. scholarship granted to the first author, as well as the inhabitants of ejido Adolfo Ruiz Cortinez (sic) for allowing us to conduct this study in their community. In addition, to the staff of the Ornithology Laboratory of the College of Biological Sciences at the Autonomous University of Nuevo Leon who provided assistance to perform this work. The comments of two reviewers contributed to improve this manuscript. María Elena Sánchez-Salazar translated the manuscript into English and provided editorial comments.

\section{Literature cited}

Aranda, J. M., C. M. del Río, L. del C. Colmenero, and V. M. Magallón. 1980. Los mamíferos de la Sierra del Ajusco. Comisión Coordinadora para el Desarrollo Agropecuario del Departamento del Distrito Federal. Ciudad de México, México.
Arellano-Nicolás, E., E. Sánchez, and M. A. Mosqueda. 2012. Distribución y abundancia de la nutria neotropical (Lontra longicaudis annectens) en Tlacotalpan, Veracruz, México. Acta Zoológica Mexicana (n. s.) 28:270-279.

BAKer, R. H., and J. K. Greer. 1962. Mammals of the Mexican state of Durango. Publications of the Museum, Michigan State University, Biological Series 2:29-159.

Bello, J., Gallina, S., and M. Equinua. 2002. Preferencia de asociaciones vegetales del venado cola blanca (Odocoileus virginianus) en dos zonas con diferente disponibilidad de agua del Noreste de México. Journal Range Management 54:537-545.

Botello, J. 2004. Evaluación del estado de la nutria de río Lontra longicaudis (Olfers 1818) en el río Cauca, zona de influencia del municipio de Cali-Departamento del Valle del Cauca. CVC. Fundación Natura, Colombia.

Botero-Botero, A. 2013. Distribución, abundancia y hábitat de la nutria neotropical Lontra longicaudis (Carnívora, Mustelidae) en la Cunca del Río La Vieja, Alto Cauca, Colombia. Tesis de Maestría. Universidad Nacional Experimental de los Llanos Occidentales "Ezequiel Zamora". Guanare, estado Portuguesa, Venezuela.

Casariego-Madorell, A. A., R. List, and G. Ceballos. 2008. Tamaño poblacional y alimentación de la nutria de río (Lontra longicaudis annectens) en la costa de Oaxaca, México. Acta Zoológica Mexicana (n. s.) 24:179-200.

ConvenCión SOBRE EL COMERCIO INTERNACIONAL DE ESPECIES AMENAZADAS de fauna y flora silvestres (CITES). 2016. Apéndices I, II y III. Convención sobre el comercio internacional de especies amenazadas de fauna y flora silvestres. UNEP. Genève, Suiza. Chanin, P. 1985. The Natural History of Otters. Facts on file publications. Nueva York, U. S. A.

Charre-Medellín, J. F., C. López-González., A. Lozano, and A. F. Guzmán. 2011. Conocimiento actual sobre la nutria neotropical (Lontra longicaudis annectens) en el estado de Durango, México. Revista Mexicana de Biodiversidad 82:1343-1347.

Colares, E. P., and H. F. Waldemarin. 2000a. Feeding of the neotropical river otter Lontra longicaudis in the coastal region of rio Grande do Sul State, southern Brazil. UICN Otter Specialist Group Bulletin 17:6-13.

Colares, E. P. and H. F. Waldemarin. 2000b. Utilisation of resting sites and dens by the neotropical river otter (Lutra longicaudis) in the south of rio Grande do Sul State, southern Brazil. UICN Otter Specialist Group Bulletin 17:12-16.

Dellafiore, C. M. and N. O. Maceira. 1998. Problemas de Conservación de los Ciervos Autóctonos de la Argentina. Mastozoología Neotropical 5:137-145.

Duque-Davilia, D. L., E. Martínez, F. J. Botello, and V. Sánchez. 2013. Distribución, abundancia y hábitos alimentarios de la nutria (Lontra longicaudis annectens Major, 1897) en el Río Grande, Reserva de la Biosfera Tehuacán-Cuicatlán, Oaxaca, México. Therya 4:281-296.

Gallo-Reynoso, J. P. 1996. Distribution of the neotropical river otter (Lutra longicaudis annectens Major, 1897) in the river Yaqui, Sonora, México. IUCN Otter Specialist Group Bulletin. 13:27-31.

Gallo-Reynoso, J. P., S. Macías-Sánchez, L. Armenta-Méndez, I. BarbaAcuña, V. A. Nuñez-Ramos, A. Loya-Jaquez, G. Ponce-García, and A. Gardea-Béjar. 2016. Letrinas de nutrias y cámaras trampa 
¿qué nos dicen? Memorias del XIII Congreso Nacional de Mastozoología, Tuxtla Gutiérrez, Chiapas.

GarCíA, E. 1981. Modificaciones al sistema de Clasificación Climática de Kóppen. Universidad Nacionao Autónoma de México. Ciudad de México, México.

García, C. M., and R. D. Quintana. 2005. Uso de canales deforestación por el lobito de río (Lontra longicaudis) en el bajo delta del Paraná en relación a sus características fisicoquímicas. Memoria de las XX Jornadas Argentinas de Mastozoología. Buenos Aires, Argentina.

Gonzalez-Christen, A., C. A. Delifin-Alfonso, and A. Sosa-Martínez. 2013. Distribución y abundancia de la nutria neotropical (Lontra longicaudis annectens Major, 1897), en el Lago de Catemaco, Veracruz, México. Therya 4:201-217.

Gori, M., G. Carpaneto, and P. Ottino. 2003. Spatial distribution and diet of the neotropical otter Lontra longicaudis in the Ibera lake (Northern Argentina). Acta Theriologica 48:495504.

Guzmán-Lenis, A. And A. Camargo-Sanabria. 2004. Importancia de los rastros para la caracterización del uso de hábitat de mamíferos medianos y grandes en el bosque Los Mangos (Puerto López, Meta, Colombia). Acta Biológica Colombiana 9:11.

Johnson R. A., AND D. W. Wicherm. 2002. Applied Multivariate statistical Analysis, eighth edition. Prentice Hall. New Jersey, U.S. A.

KRUUK, H. 1995. Wild otters: Predation and populations. Oxoford University Press. Oxford, Great Britain.

LEOPOLD, A. S. 1959. Wildlife of Mexico: the game birds and mammals. University of California Press. Berkeley, U. S. A.

Litvains, J. A., K. Titus, and E. M. Ardenson. 1996. Measuring vertebrate use of terrestrial habitat and foods. Pp. 254-274, in Research and Managment for Wildlife and Habitat (Hout, B., ed.). Wildlife Society. Maryland, U. S. A.

LoDÉ, T. 1993. The decline of otter Lutra lutra populations in the region of the Pays de Loire, western France. Biological Conservation 65:9-13.

López-Martín, J. M., J. Jiménez, And J. Ruiz-Olmo. 1998. Caracterización y uso de hábitat de la nutria Lutra lutra (Linné, 1758) en un río de carácter mediterráneo. Galemys 10:175-190.

MACíAS-SÁNCHEZ, S. 2003. Evaluación del hábitat de la nutria neotropical (Lontra longicaudis Olfers, 1818) en dos ríos de la zona centro del estado de Veracruz, México. Tesis de Maestría. Instituto de Ecología, A. C. Xalapa, México.

Mason, C. F., AND S. M. Macdonald. 1987. The use of spraints for surveying otter Lutra lutra populations: An evaluation. Biological Conservation 41:167-177.

MAYOR-VICTORIA, R. 2008. Hábitat y dieta de la nutria neotropical Lontra longicaudis Carnivora, Mustelidae en el río Roble, Alto Cauca, Colombia. Tesis de licenciatura. Universidad del Quindío. Armenia, Colombia.

MAYOR-VICTORIA, R. AND Á. Botero-Botero. 2010. Uso del hábitat por la nutria neotropical Lontra longicaudis (Carnivora: Mustelidae) en el río Roble, Alto, Cauca, Colombia. Boletín Científico. Centro de Museos. Museo de Historia Natural 14:121-130.

Noss, A. J., E. Cuéllar, and R. L. Cuellar. 2003. Hunter SelfMonitoring as a basis for biological research: data from the
Bolivian Chaco. Mastozoología Neotropical 10:49-67.

Prenda, J. and C. Granado-Lorencio. 1996. The relative influence of riparian habitat structure and fish availability on otter Lutra lutra L. Sprainting activity in a small Mediterranean catchment. Biological Conservation 76:9-15.

RICHARD, P., R. RozzI, P. FeInsingeR, R. DiRzo, and F. Massardo. 1998. Fundamentos de conservación biológica. Perspectivas Latinoamericanas. Fondo de Cultura Económica. Ciudad de México, México.

RHeingantZ, M. L., AND C. S. Trinca. 2015. Lontra longicaudis. The IUCN Red List of Threatened Species 2015: e. T12304A21937379. http://dx.doi.org/10.2305/IUCN. UK.2015-2.RLTS.T12304A21937379. Downloaded on 22 February 2016.

Ruiz-Olmos, J., J. Jiménez, S. Palazón, M. Dellies, C. Bravo, and F. BUENO. 1998. Factores que han determinado la situación actual de las poblaciones de nutria y propuestas de gestión. Pp. 223-242, in La nutria en España ante el horizonte 2000 (Ruiz-Olmo, J., and M. Delibes., eds.). Sociedad Española para la Conservación y Estudio de los Mamíferos (SECEM) Grupo Nutria. Barcelona-Sevilla-Málaga, España.

Ruiz-Olmo, J., D. SAAVEDRA, AND J. JIMÉNEZ. 2001. Testing the surveys and visual and track censuses of Eurasian otters (Lutra lutra). Journal of Zoology London 253:359-369.

Samuel, M. D., D. J. Pierce, and E. O. Garton. 1985. identifying areas of concentrated use within the home range. Journal of Animal Ecology 54:711-719.

Santiago-Plata, V. M., J. D. Valdez-Leal, C. J. Pacheco-Figueroa, F. de la Cruz-Burelo, and E. J. Moguel-Ordónenz. 2013. Aspectos ecológicos de la nutria neotropical (Lontra longicaudis annectens) en el camino La Veleta en la Laguna de Términos, Campeche, México. Therya 4:265-280.

Secretaria de Medio Ambiente y Recursos Naturales (SEmarnat). 2010. Norma Oficial Mexicana NOM-059-SEMARNAT-2010. Protección ambiental-especies nativas de México de flora y fauna silvestres-Categorías de riesgo y especificaciones para su inclusión, exclusión o cambio-Listas de especies en riesgo. Diario Oficial, jueves 30 de diciembre de 2010.

Servín, J., E. Chacón, N. Alonso-Pérez, and C. Huxley. 2003. New records of mammals from Durango, México. The Southwestern Naturalist 48:136-138.

Sutherland, W. J. 2006. Ecological Census Techniques. Cambridge University Press. Cambridge, United Kingdom.

Tellería, J. L. 1986. Manual para el censo de los vertebrados Terrestres. Universidad Complutense. Ediciones Raíces. Madrid, España.

WalKeR, S. R., A. J. Novaro, AND J. D. Nichols. 2000. Consideraciones para la estimación de abundancia de poblaciones de mamíferos. Journal of Neotropical Mammal 7:73-80.

ZAR, J. H. 1999. Biostatistical analysis, fourth edition. Prentice Hall. New Jersey, U. S. A.

Associated editor: Consuelo Lorenzo

Submitted: January 6, 2017; Reviewed: March 2, 2017;

Accepted:April 17, 2017; Published on line: March 26, 2017. 